\title{
Patient Rights and Local Government Responsibilities: Human Rights Perspective
}

\author{
Andi Muhammad Sofyan \\ Professor at Faculty of Law, Hasanuddin University, Makassar, Indonesia
}

\begin{abstract}
Nowadays, the implementation of health care is often encountered a conflict between health personnel and recipients of health services or patient. Actually, these cases have happened for a long time, but mostly protracted because of different views by health personnel or workers. The results show that the absence of national service standards causes each hospital creates each procedure according to a condition. It causes different standard operating procedures in each hospital. If reviewed properly that every hospital with the same type should have the same standard operating procedures, so that people who come to visit for treatment no longer assume different types of hospitals of the same type. Likewise, if there is an incident of malpractice in a hospital of the same type, then the law enforcement officers will easily to examine by simply checking the service standards set by the government by looking the type of hospital. In this context, the Provincial Government of South Sulawesi is consistent and truly carries out the supervisory function of health workers, plans carefully the infrastructure of hospitals, opens the admission of education for doctors or other health workers so that the fulfillment of health personnel can be realized and there are no doctors or other health personnel leave the assignment at duty hours, especially those with the status of civil apparatus, and give the opportunity to the region citizen to take education and returning to their regions to serve so that the people in the area who will seek treatment are also touched by the competent personnel in their fields.
\end{abstract}

Keywords: Government; Liability; Responsibility; Health Right: Patient Rights; Local Government

DOI: $10.7176 / J L P G / 81-14$

\section{Introduction}

Healthy represents a condition that always expected and desired by every human in their life. Therefore, everyone tries to be healthy so that they can live well. In the Indonesian Health Act, it is emphasized that "Everyone has the right to health". Thus, everyone has the same rights to access resources in the health sector and has the right to obtain safe, quality and affordable health services.

In health care, in addition requires health personnel, it also need assistance from other parties, so that health care can achieve as expected. The other party is health facilities such as hospitals. In the hospital, health personnel work to provide health care for those who need it. ${ }^{1}$ It occurs a legal relationship in the form of therapeutic transactions or healing agreements between those who provide health care and those who receive health care.

At a practical level, however the implementation of health care is often encountered a conflict between health personnel and recipients of health services or patient. The relationship between health personnel and recipients of health services is based on 2 (two) characteristics, namely the agreement on a care or services (consensual) and a trust (fiduciary) between service providers and recipients of health services. ${ }^{2}$ Conflicts between parties or malpractice in health services, especially in the service on Obstetrics Genecology departments is one of the problems among many problems in the implementation of health services, and become a medical problem in this country.

According to the WHOs data, $99 \%$ of maternal deaths due to labor or birth problems occur in developing countries. The ratio of maternal mortality in developing countries is the highest, 450 maternal deaths per

\footnotetext{
${ }^{1}$ Persson, Karl. "The right perspective on responsibility for ill health." Medicine, Health Care and Philosophy 16, no. 3 (2013): 429-441.

${ }^{2}$ J. Gunadi, 2007. Dokter, Pasien dan Hukum, FK UI, Jakarta, p. 19.
} 
100.000 live births. When compared with the ratio of maternal mortality in nine developed countries and 51 developing countries. ${ }^{1}$

In Indonesia, it is estimated 14 million cases of hemorrhage in labor. At least 128.000 women experience until death. Postpartum hemorrhage, especially primary postpartum hemorrhage is the most common cause of maternal death. Primary postpartum hemorrhage is postpartum hemorrhage that occurs within the first 24 hours of birth. Many factors cause death in maternity mothers or postpartum, both directly and indirectly, but most of them are direct causes. The direct cause consists of various cause, the most dominating is eclampsia. $^{2}$

Actually, these cases have happened for a long time, but mostly protracted because of different views by health personnel or workers, scientists or legal practitioner in highlighting cases that occur, especially in gynecology department. In the reality that the failure of health services is also due to the consequences of the late handling of patients who need immediate handling, it encompasses an emergency. There are 2 (two) problems that can arise in an emergency, namely the patient comes to the hospital with a disease condition that is already unable to be helped and is already severe or those comes with a referral from another health facility with conditions that are also in an emergency in other words late referring to the hospital.

As a comparison, in some developing countries, peoples often pass through early-level health facilities, leading to higher referral rates in advanced health facilities. The causes of high referral rates in advanced health facilities are due to lack of utilization of lower-level health facilities or lack of quality of referral services at lower levels, whereas if we see that diseases do not recognize the level of health services, the government needs to review the levels of health services to be fair and provide health rights for all Indonesian people, as mandated by the 1945 Constitution of the Republic of Indonesia as stated in the Pancasila that "Social Justice for all Indonesian People".

In terms of health law, the absence of national service standards will harm not only the health workers, but also the community as recipients of services. Therefore, there is a need for national service standards in health services to protect the community as recipients of health services or health workers themselves. Technological advances in biomedical fields coupled with the ease of obtaining information and communication in this globalization era make it easier for patients to get second opinions from various parties, both from domestic or foreign level, which if doctors or health personnel are not careful in giving explanations to patients, will result in reduced patient trust in the doctors and health personnel. ${ }^{3}$

\section{Minimum Service Standards for Health Services}

In order to improve the health level of the community, both in urban and rural areas, the government must establish clear and measurable standards so that it is easily implemented in each region. To avoid inequality in its implementation, there must be a minimum standard that can be applied to all regions. Minimum service standards that have been set by the Government have not yet been fully implemented by all regions in Indonesia. This is understandable given that health problems are a basic need of people whose reach is very broad.

If the service agency has a service standard, then the service is called very good or best or will be excellent, when it can or is able to satisfy the party served (customer). Such excellent service is suitable to the expectation of customer. Certainly, if an excellent service can be measured, for service providers that do not have service standards, it is necessary to make service standards in accordance with their duties and functions. If we consider carefully, the service process does not only includes activities when customers face to face directly with service personnel, but it also includes activities before and after. A service will not be excellent if it does not completely cover it. Excellent service is a comprehensive service.

Based on the Decree of the Minister of Administrative Reform No.63/KEP/M.PAN/7/2003 that in providing public services must contain the following elements:

a. Rights and obligations for providers and recipients of public services must be clear and known by each.

\footnotetext{
${ }^{1}$ Source: http://www.who.int/news-room/fact-sheets/detail/maternal-mortality Accessed on 8 January 2018.

${ }^{2}$ Fariza Dwicahyaning Putri, Kondisi Pembeda Volume Perdarahan Kala IV, Jurnal Biometrika dan Kependudukan, Vol.3 No. 2 December 2014, p. 121

${ }^{3}$ Crisdono M. Achadiat, 2004. Dinamika Etika dan Hukum Kedokteran Dalam Tantangan Zaman, Penerbit Buku kedokteran, Jakarta p, 21
} 
b. The arrangement of any public service must be adjusted to the conditions of the needs and ability of the community to pay based on the prevailing laws and regulations while still adhering to efficiency and effectiveness.

c. The quality of the process and the outcome of public services must be endeavored to provide security, comfort, smoothness and legal certainty that can be accounted for.

d. If public services by government agencies to be expensive, the relevant government agency is obliged to provide opportunities for the community to participate in organizing it in accordance with the prevailing laws and regulations.

The Public Services Acts (officially named Act No. 25 of 2009 concerning Public Services) is a law that regulates the principles of good governance as an effectiveness of government functions themselves. The State is obliged to serve every citizen and population to fulfill their basic rights and needs within the framework of public services as mandated by the 1945 Constitution of the Republic of Indonesia.

Building public trust in public services as conducted by public service providers is an activity that must be conducted in line with the expectations and demands of all citizens and population about improving public services.

Agencies that perform public services can develop their own patterns of service delivery in an effort to find and create innovations to improve public services. The development of the pattern of public service is intended to follow the principles and objectives of the implementation of public services.

The drafting of the principles and objectives of public services is used as a guideline in public services by government agencies and can be used as an indicator of the quality of services that have been given to the welfare of people' lives in accordance with applicable regulations.

Health is a basic need of every human being and as a capital of every citizen and every nation in achieving its goals and achieving prosperity. A person cannot fulfill all of their life' needs if they are in an unhealthy condition, so that health is the capital of each individual to continue their life properly.

The government has a responsibility to ensure every citizen obtains quality health services according to needs. As a basic need, each individual is responsible for fulfilling the their life needs and peoples they are responsible for, so that basically meeting the needs of the community for health is the responsibility of every citizen and government.

Discussing about health services as our responsibility and seeing how health care is very primary where someone who needs help at that time also help as if it does not provide certainty either in terms of acceptance by health services or hospitals that end with disappointments and conflicts between officers and service recipients. Where the government has specialized that health is one of six concurrent affairs is compulsory and related to basic services. The six affairs as follows:

1. Education

2. Health

3. Public Works and Spatial Planning

4. Public Housing and Settlement Areas

5. Peace and Public Order and Community Protection

6. Social

By the inclusion of health in compulsory affairs, a Minimum Service Standard was designed by the Ministry of Health, which then changed from the Performance of Ministry Program to the Performance of Regional Government which has the consequences of reward and punishment, so that the provincial government is expected to ensure the availability of resources (facilities, infrastructure, tools, personnel and money or costs) so that the process of implementing the Minimum Service Standards runs adequately. Because the condition of provincial government resources throughout Indonesia is different in carrying out these six functions, the implementation of these matters is regulated by the Minimum Service Standards to ensure the availability of these services for all citizens. ${ }^{1}$

Minimum Service Standards are provisions concerning the type and quality of basic services which are mandatory government affairs that are entitled to be obtained by every citizen at a minimum. Every citizen in accordance with their nature is obliged to fulfill the basic needs of their life by utilizing all of their

\footnotetext{
${ }^{1}$ Mathur, P. (2014). Role of Hospital Housekeeping and Materials Management Including Disinfection and Waste Management. In Hospital Infection Prevention (pp. 81-89). Springer, New Delhi, pp 23-24
} 
human potential. On the contrary, the Central and Local Governments are obliged to ensure that every citizen can exercise their rights to fulfill their needs without obstacles from any party.

The foregoing things make all elements united to work together to achieve the targets of the Minimum Service Standards, including the fulfillment of human resources in the health sector.

In this study, the author see that the Minimum Service Standards also become very strategic in relation to the implementation of National Health Insurance, which until now is still problem either constrained by the problems of long procedures and bureaucracy and financial problems and other technical problems. The application of the Minimum Service Standards will strengthen the promotion and preventive aspects so that it is expected to impact on the reduction in the number of curative cases that must be borne by the National Health Insurance.

Likewise, the Minimum Service Standards in hospitals that aim to improve services at the higher-level of service in its service receive referrals from lower-level health facilities which of course all the shortcomings and inability of lower-level services are at the higher-level services, namely hospitals.

Government efforts to fulfill the people' rights in the health sector at the higher-level. Nonetheless, there are still many complaints and dissatisfaction with about the services provided by the government, both the central and local governments. In fact, since 2005 the Government Regulation No. 65 of 2005 has been issued which contains provisions concerning the Guidelines for the Preparation and Application of Minimum Service Standards even reinforced by the Regulation of Domestic Affairs No. 6 of 2007 concerning Technical Guidelines for Preparing and Determining Minimum Service Standards.

The policy of the central government regarding the Minimum Service Standards by the provincial government of South Sulawesi has been enacted in the form of a Governor Regulation concerning Regional Minimum Service Standards. Minimum Service Standards as is known are a reference used to measure the quality and quantity of public services provided including public health services.

In the implementation of these policies, there are several problems that affect such as the lack of maximum types of services provided by health care workers, dispositions or attitudes given by health workers that are considered by some to be poor, the availability of health workers/personnel, and facilities and infrastructure to support health services, as well as other problems related to hospital services. Therefore, such problems in the implementation of the Minimum Service Standards, it is specified by creating and designing Standard Operating Procedures to minimize problems and even solve problems, for example in health services, the absence or minimization of conflicts, malpractice and other services and it is expected to run smoothly and community satisfaction levels are met.

\section{Government Responsibility for Health Services in a Legal Perspective}

Hospital is a health service institution that applies complete individual health services that provide inpatient, outpatient and emergency services. According to Act 44 of 2009 concerning Hospitals in Article 1 paragraph 1 "hospital is required to be able to provide the best health services for patients specifically and for the communities at large."

The quality of the hospital is largely determined by 2 (two) main factors, namely service by hospital staff and buildings and infrastructure of the hospital itself. The impact that can be caused when these two factors are not met properly is the poor hospital service, both in normal conditions and when a disaster occurs.

Improving public health services is inseparable from the availability of health facilities. One of the health development missions in realizing the vision of Healthy Indonesia 2015 is to maintain and improve quality, equitable and affordable health services, it means that one of the responsibilities of the health sector is to ensure the availability of the best, quality, equitable and affordable health services for the community. ${ }^{1}$ To achieve this, various health care efforts have been carried out.

In addition, in the aspect of resources also need to be supported by the availability of facilities needed in the implementation of health services. The condition of facilities and infrastructure at some of the hospitals is that the existing health facilities are different from one hospital to another. From these data the author saw that the lack of health facilities and infrastructure made it possible for a poor management of public

${ }^{1}$ Andi Muhammad Sofyan. (2017). Euthanasia: Concept and Rule of Law in Indonesia. IISTE, Journal of Law, Policy and Globalization, Vol. 58: 27-32 
health services. ${ }^{1}$ This aspect of resources is one of the supporting factors in creating a comprehensive health service.

An interview with the head of the Health Office were represented by the secretary of the Health Office that the Provincial Government of South Sulawesi considered that the weaknesses of public health services, especially in hospitals under the auspices of the Provincial Government of South Sulawesi were inadequate facilities and infrastructure, and the most noticeable is access to information about health services that will create an integrated health service for the community.

In addition, the attitude of health personnel in which there are personnel who do not obey the professional ethics they have received during education. Therefore, the disposition factor must be improved so that it can provide good health services to the community. However, according to him, such weakness occurs due to factors including:

The increasing number of community needs for public health services as a factor that supports the implementation of public health service policies in several hospitals in South Sulawesi Province. Environmental factors are the next factor in assessing the performance of health services in the community. As already known, the environment is an important factor in the implementation of health services in several hospitals studied. Environmental conditions are one of the supporting factors in the implementation of a comfortable health service. A clean and comfortable environment is part of policy implementation that promotes a good health service to the community.

Resource is one of the important factors in the process of implementing a program or policy, without the support of adequate resources, both in the form of numbers and abilities or skills and managerial abilities in implementing health services in several hospitals.

In the implementation, it is necessary for the implementer to support the implementation of the policy properly. Without the personnel to run a program, any policy cannot work and only remains as a document without realization. Therefore, the availability of executors who are competent enough to encourage the success of the policy. To look back at the reality, the conditions of personnel or health workers that all health facilities still need improvement and still less than what is expected and the role of government is very strong to make improvements.

The development of extensive performance and it is intended that more work areas are included in measuring performance; it also that more management functions are included in measuring performance, while external development is interpreted by more external parties calculated in measuring performance.

Process performance describes whether a process designed in an organization allows the organization to achieve its mission. Individual performance describes how far someone has carried out the main activities so as to achieve results as determined by the institution. Organizational performance is related to how far an institution has carried out all the main activities so as to achieve the mission or vision of the organization.

Performance assessment can be used as a measure of the success of an organization within a certain period of time. These assessments can also be used as input for further improvement or improvement in organizational performance. ${ }^{2}$ Hence, the government proposes 3 (three) concepts that can be used to measure the performance of public organizations, as follows:

\section{Responsiveness}

It describes the ability of public organizations to run their mission and objectives, especially to meet the needs of the community. Responsiveness assessment is based on organizational and community data, organizational data is used to identify types of organizational activities and programs, while service user community data is used to identify community demand and needs.

2. Responsibility

The implementation of public organization activities is conducted in accordance with the correct administrative principles or in accordance with organizational policies both implicit and explicit. It

\footnotetext{
${ }^{1}$ Wahyudi, S. (2011). Tanggung Jawab Rumah Sakit terhadap Kerugian Akibat Kelalaian Tenaga Kesehatan dan Implikasinya. Jurnal Dinamika Hukum, 11(3), 505-521.

${ }^{2}$ Haun, J. N., Valerio, M. A., McCormack, L. A., Sørensen, K., \& Paasche-Orlow, M. K. (2014). Health literacy measurement: an inventory and descriptive summary of 51 instruments. Journal of Health Communication, 19(sup2), 302333.
} 
can be assessed from an analysis of documents and reports on organizational activities. It is conducted by matching the implementation of activities and organizational programs with administrative procedures and provisions in the organization.

3. Accountability

It refers to how large the policies and activities of the company are subject to political officials appointed by the people, it can be obtained from various sources, such as the assessment of representatives of the people, political officials, and the community.

Organizational objectives must be planned as best as possible by involving members of the organization, from formulation to implementation or effort to achieve it, shows the position, authority and responsibility of each in a cooperation and work procedures will be very beneficial for the organization in terms of helping the coordination and integration of work, and help monitor the work of the organization so that it can be known whether an activity is going well or bad.

As described above, the measurement of the performance of public organizations can be done internally and externally. Internal assessment is to know whether the process of achieving the objectives is in accordance with the plan when viewed from the process and time, while the external assessment is done by measuring community satisfaction with the services provided by the organization. For organizations, effective performance means that output is maintained even if the amount of work is small, or productivity is increased. It should be emphasized that the effectiveness of person' performance depends on the organization itself, whether it has a clear vision, mission, strategy and goals.

\section{Conclusion}

The absence of national service standards causes each hospital creates each procedure according to a condition. It causes different standard operating procedures in each hospital. If reviewed properly that every hospital with the same type should have the same standard operating procedures, so that people who come to visit for treatment no longer assume different types of hospitals of the same type. Likewise, if there is an incident of malpractice in a hospital of the same type, then the law enforcement officers will easily to examine by simply checking the service standards set by the government by looking the type of hospital.

It recommended that the government should be responsible establish the National Service Standards in each hospital of the same type in which it should have the same standard operating procedures in its care. In this context, the Provincial Government of South Sulawesi is consistent and truly carries out the supervisory function of health workers, plans carefully the infrastructure of hospitals, opens the admission of education for doctors or other health workers so that the fulfillment of health personnel can be realized and there are no doctors or other health personnel leave the assignment at duty hours, especially those with the status of civil apparatus, and give the opportunity to the region citizen to take education and returning to their regions to serve so that the people in the area who will seek treatment are also touched by the competent personnel in their fields.

\section{References}

Crisdono M. A. (2004). Dinamika Etika dan Hukum Kedokteran Dalam Tantangan Zaman, Buku Kedokteran, Jakarta.

Fariza Dwicahyaning Putri, Kondisi Pembeda Volume Perdarahan Kala IV, Jurnal Biometrika dan Kependudukan, Vol.3 No. 2 December 2014.

Haun, J. N., Valerio, M. A., McCormack, L. A., Sørensen, K., \& Paasche-Orlow, M. K. (2014). Health literacy measurement: an inventory and descriptive summary of 51 instruments. Journal of Health Communication, 19 (sup2), 302-333.

J. Gunadi, (2007). Dokter, Pasien dan Hukum, FK UI, Jakarta.

Mathur, P. (2014). Role of Hospital Housekeeping and Materials Management Including Disinfection and Waste Management. In Hospital Infection Prevention (pp. 81-89). Springer, New Delhi, pp 23-24. 
Persson, Karl. "The right perspective on responsibility for ill health." Medicine, Health Care and Philosophy 16, no. 3 (2013): 429-441.

Sofyan, A. M. (2017). Euthanasia: Concept and Rule of Law in Indonesia. IISTE, Journal of Law, Policy and Globalization, Vol. 58: 27-32

Wahyudi, S. (2011). Tanggung Jawab Rumah Sakit terhadap Kerugian Akibat Kelalaian Tenaga Kesehatan dan Implikasinya. Jurnal Dinamika Hukum, 11(3), 505-521.

WHO. Source: http://www.who.int/news-room/fact-sheets/detail/maternal-mortality Accessed on 8 January 2018. 